\title{
ANALYZE RETURN ON EQUITY AND WEIGHTED AVERAGE COST OF CAPITAL LINKAGES TO FIRM VALUE
}

\author{
Deuis Kartinah*1, Dicky Jhoansyah ${ }^{2}$, Faizal Mulia $Z^{3}$ \\ Universitas Muhammadiyah Sukabumi, Indonesia*123 \\ Deuiskartina04@gmail.com¹ , dicky.jhoansyah@gmail.com ${ }^{2}$, faizal 88@ummi.ac.id ${ }^{3}$
}

\begin{abstract}
The company's stock price which always experiences a decline is the background of this research. This study aims to determine the effect of return on equity (ROE) and Weighted Average Cost of Capital (WACC) on firm value in the textile and garment sector which is listed on the Indonesia Stock Exchange. This study using secondary data from is Financial statements of textile and garment companies from 2013 to 2018 obtained through the website Indonesia Stock Exchange. The analytical method used is multiple linear regression and data analysis using IBM Statistics 26. Based on the result of the analysis it can be concluded that return on equity and weighted average cost of capital has a significant effect on firm value with $R^{2}$ equal to 0,329 , which means the contribution of the independent variable to firm value by Price book value (PBV) in textile and garment companies is equal to $32,9 \%$ and the remainder equal to $68,1 \%$ can be explained by other variables outside this study, and based on the value of $F$ with the values 6.606 shows that the simultaneous correlations of independent variables namely ROE and WACC with the dependant variable firm value.
\end{abstract}

Keywords: Firm Value; Return on Equity; Weighted Average Cost of Capital

\section{INTRODUCTION}

The textile and garment industry is one of the national priority industries which has the perspective to be developed. With a population of more than 250 million in Indonesia, it is a very potential market. In this case, the Textile and Garment Business is a business that refers to the needs of the people who use the textile products for daily life activity (Kemenperin, n.d.).

Companies in carrying out their business activities must have a goal, one of the objectives of the company is to increase the value of the company by maximizing corporate profits that will make stock prices increase. Company value gives a positive signal in the eyes of investors to invest capital in a company. As for creditors, the company's value reflects the company's ability to pay its debts so that creditors do not feel worried about giving loans to the company. Then, to minimize risk and to automate returns, information, analysis, and calculation are very necessary by investors before making a decision investment in a company on the capital market (Lutfiana \& Jhoansyah, 2019). Harmono (2017) describes that company value is the performance of a company which is reflected by the price of shares formed by the demand and supply of the capital market which reflects the public's assessment of the company's performance.

Based on this Background the value of the company which is reflected by the stock price, the price of the shares of textile and garment companies listed on the Indonesian stock exchange are as follows: 


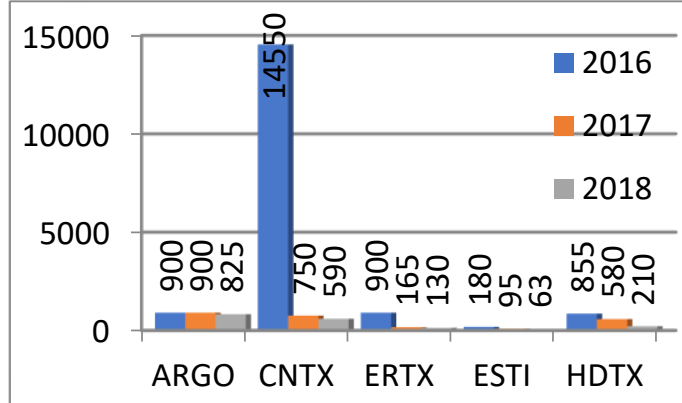

Figure 1. The Price of The Shares of Textile and Garment Companies Listed on the Indonesian Stock Exchange

Source: Processed by the author (2020)

The position of textile and garment companies is shown in figure 1. States that performance is less than the maximum because some companies experience consistent stock price decrease every year. If the stock price continues to decline will affect investor confidence to invest in the company. Stock prices that continue to decline mean the same as a decline in the firm value, the makes investors think the company is unable to achieve company goals. Important corporate value requires companies to make decisions or policies, especially in the financial sector that can maximize corporate value, one of which can be created through making the right funding decisions (Ali \& Miftahurrohman, 2014).

In this study author use Price book value (PBV) or Market to book ratio because according to Puspitasari (2013) firm value can be indicated by price book value, and according to Fahmi (2015) one approach to determine a company's stock valuation is to use Price Book Value (PBV). Using PBV can show the company can create corporate value.

Investors usually react to the company's financial performance in generating profits that the company can produce because an investor would want to obtain profit-sharing in the form of dividends or capital gains (Suripto, 2015). Some factors can be taken into consideration by management for making policies company. so that the right policy will be able to maximize the value of a company.

The independent variable used to measure the profit generated by the company in this study is Return on Equity. Return on Equity is the ratio to measure net income after tax with own capital. This ratio is used to determine the effectiveness and efficiency of self-management of capital carried out by management in generating profit after tax (Sudana, 2015). The second independent variable is the Weighted average cost of capital that weighted average between the cost of interest and cost of own capital (Harmono, 2017). That means the weighted average cost of capital is the level the company expects to pay on average to all its security holders to finance its assets.

Puspitasari (2013) research shows that DER, DR, ROE, LNEPS, AGR, SGR, LNCR, and ATR together have a significant effect on firm value, it can be concluded that return on equity has a significant effect on Price book values. The results of Rahmantio, Saifi, \& Nurlaily (2018) research shows that DER, ROE, and company size simultaneously have a significant effect on firm value.

Sulistiyo (2013) research shows that the proportion of the weighted average cost of capital (WACC) influences the value of the company proxied by the stock price. other studies found that there is a significant impact of the weighted average cost of capital on firm value (Sattar, 2015). In this study the research paradigm used is a dual paradigm with two independent variables $(\mathrm{X} 1, \mathrm{X} 2$,$) and one dependent variable (\mathrm{Y})$ which is described as follows paradigm : 


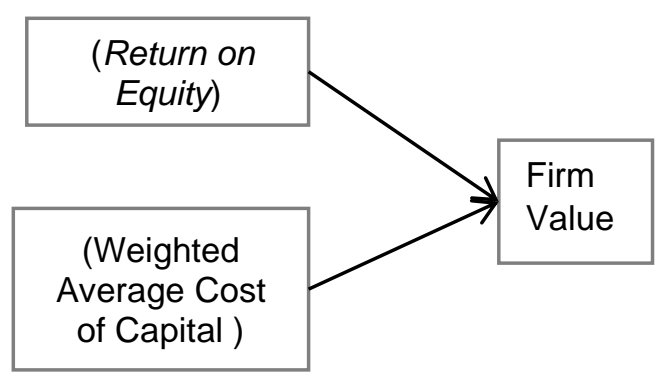

Figure 2. Research Paradigm

Source: Processed by the author (2020)

Based on the Description above, the purpose of this study is to determine the level of relationship between return on equity and the weighted average cost of capital on firm value in the textile and garment companies period 2013-2018.

\section{METHODS}

The object of research here is a textile and garment company listed on the Indonesia Stock Exchange in the period 2013 - 2018. The research method uses quantitative and associative research. The sampling technique in this study is purposive sampling, based on the criteria of the authors of the existing population.

Table 1. Samples of Companies in the Textile and Garment Listed on the Indonesian Stock Exchange

\begin{tabular}{ccc}
\hline No & Issuer Name & $\begin{array}{l}\text { Stock } \\
\text { code }\end{array}$ \\
\hline 1 & Agro Pantes Tbk & ARGO \\
2 & Century Textile Industry & CNTX \\
& Tbk & \\
3 & Eratex Djaja Tbk & ERTX \\
4 & Ever Shine Tex Tbk & ESTI \\
5 & Panasia Indo Resource & HDTX \\
& Tbk & \\
\hline
\end{tabular}

Source: Data from IDX that has been processed by the author (2020)

Data collection techniques in this study using secondary data, namely, literature study, and documentation that Financial statements. Data analysis techniques in this study are horizontal analysis with IBM SPSS statistical software 26 is a Multiple regression test. To find out the value of research variables using the following formula:

The dependent variable used in this study is the company value measured: Price to Book Value (PBV). According to Sudana (2015), the formula for finding company value as indicated by Price to Book Value is:

$$
P B V=\frac{\text { Stock Price }}{\text { book value }}
$$

The independent variables used in this study are: Return on Equity (ROE) is a ratio related to the profit generated on own capital. According to Kasmir (2018), Return on Equity is formulated as follows:

$$
R O E=\frac{\text { Earning After }- \text { tax }}{\text { Equity }}
$$


The weighted average cost of capital is the level the company expects to pay on average to all its security holders to finance its asset. Is formulated as follows :

$$
W A C C=W_{d} \cdot K_{d}(1-t)+W_{p} K_{p}+W_{e} K_{e}
$$

\section{RESULTS AND DISCUSSION}

The coefficient of determination to determine the amount of contribution of the influence of independent variables on the dependent variable. stated that Variable y can be explained by variable $x$ by $r^{2} \%$ and the rest is explained by other variables. Following are the results of testing the coefficient of determination using IBM SPSS Statistics 26 software :

Table 2. Coefficients of Determination

\begin{tabular}{|c|c|c|c|c|}
\hline \multirow[b]{2}{*}{ Model } & \multicolumn{3}{|c|}{ Model Summary } & \multirow[b]{2}{*}{$\begin{array}{l}\text { Std. Error of } \\
\text { the Estimate }\end{array}$} \\
\hline & $\mathbf{R}$ & R Square & $\begin{array}{l}\text { Ádjusted R } \\
\text { Square }\end{array}$ & \\
\hline 1 & $.573^{\mathrm{a}}$ & .329 & .279 & 1.15441 \\
\hline \multicolumn{5}{|c|}{ a. Predictors: (Constant), WACC (X2), ROE (X1) } \\
\hline
\end{tabular}

Based on the table above, can see the correlation between ROE and WACC variables with the company value (PBV) in the Textile and Garment Industry listed on Indonesia Stock Exchange is 0,573 or $57,3 \%$. The coefficient determination is used to find out how feasible ROE (X1) and WACC (X2) explain the value company.

The value can be obtained directly through table 2 . That is in the $R$ square table that is determination coefficient of 0,329 or $32,9 \%$. Based on calculations and data processing above, it can be seen that the magnitude of the effect of Return on Equity and Weighted Average Cost of Capital on the firm value in the Textile and Garment Companies listed in the Indonesia Stock Exchange. that is equal to 32.9 and the rest equal to $(100 \%-32.9 \%)=68,1 \%$ explained by other variables outside of this study

Next, the criteria of the coefficient of determination can be determined which shows that the effect of ROE and WACC on the value of the company (PBV) on the Textile and Garment Industry listed on the Indonesia stock exchange is included in the weak criteria because the $\mathrm{R}$ square value is 0,329 that mean it close to zero.

Multiple linear regression analysis is used to predict how far the change in the value of a variable if the value of other variables is raised. Regression test results using IBM SPSS Statistics 26 software are as follows:

Table 3. Result of Multiple Linear Regression Analysis

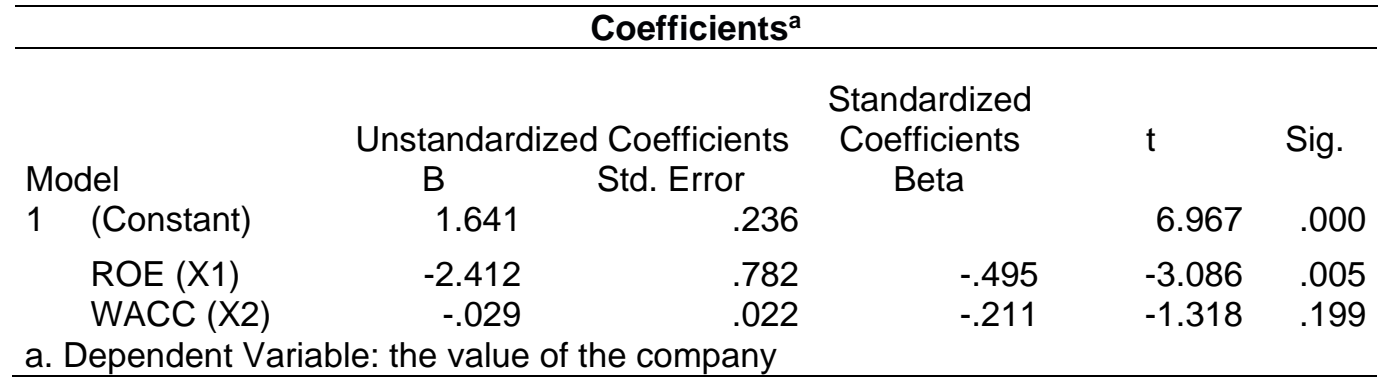

Source: Processed by the author on SPSS 26 (2020) 
Multiple linear regression test results using IBM SPSS Statistical software 26 there are multiple regression equations between the independent variables namely Return on Equity and Weighted average cost of capital with the dependant variable firm value is: $Y$ $=1.641-2.412 \mathrm{X}_{1}-0.029 \mathrm{X}_{2}$.

Then, based on the results of the regression analysis can be explained as follows: A constant value of 1.641 means that all independent variables are assumed to be zero then the value of the company will be 1.641, Return on Equity coefficient value of -2.412 mean when the return on equity has added one unit then the dependant variable that is firm value will decrease by 2.412 , and Weighted average cost of the capital coefficient value of $-0,029$ mean when Weighted average cost of capital has added one then the dependant variable that is firm value will decrease by 0,029 .

F-test is used to determine the relationship of independent variables to the dependent variable in influencing together. The following F-Test results were processed using IBM SPSS Statistics 26 software:

Table 4. Result of F-Test

\begin{tabular}{|c|c|c|c|c|c|}
\hline \multicolumn{6}{|c|}{ ANOVA $^{a}$} \\
\hline $\begin{array}{l}\text { Model } \\
1 \quad \text { Regression }\end{array}$ & $\begin{array}{r}\text { Sum of Squares } \\
17.608\end{array}$ & $\mathrm{df}_{2}$ & $\begin{array}{r}\text { Mean Square } \\
8.804\end{array}$ & $\begin{array}{l}F \\
6.606\end{array}$ & $\begin{array}{l}\text { Sig. } \\
.005^{b}\end{array}$ \\
\hline $\begin{array}{l}\text { Residual } \\
\text { Total } \\
\text { a. Dependent V } \\
\text { b. Predictors: (C }\end{array}$ & $\begin{array}{r}35.982 \\
53.590 \\
\text { e: The Value of Th } \\
\text { int), WACC (X2), }\end{array}$ & $\begin{array}{c}27 \\
29 \\
\text { Com } \\
\text { DE }(X\end{array}$ & $\begin{array}{l}\text { pany } \\
\text { (1) }\end{array}$ & & \\
\hline
\end{tabular}

Source: Processed by the author on SPSS 26 (2020)

Based on table 4. Can be seen the determination of Return on Equity and Weighted average cost of capital on Firm value, based on simultaneous test results (f-test) the result obtained a $F_{\text {count }}$ of 6,606 with a significance level of $0,005<0,05$. It means that return on equity and weighted average cost of capital together affect the firm's value. Based on the $F_{\text {table }}$ with the numerator DK $=2$ and the denominator, DK $=30-2-1=27$ with the error level set at $5 \%$, the $F_{\text {table }}$ value of 3.35 is obtained. Then, the result of testing the hypothesis $F_{\text {count }}>F_{\text {table }}$ is $6.066>3.35$. the $F_{\text {count }}$ greater than the $F_{\text {table }}$ which shows return on equity and Weighted average cost of capital in textile and garment companies simultaneously determine the firm value.

Based on the results of the study, this study also supports previous studies that there is a significant simultaneous relationship between the independent variables namely return on equity and a weighted average cost of capital to the dependant variable that is firm value as indicated by PBV.

But in this study, ROE, WACC, and Firm value show a less strong relationship with the contribution of independent variables. namely ROE and WACC less large to set the dependant variable that is the firm value (PBV). Then through increasing the value of ROE and WACC the company can make the firm value go down which is associated with the value of the stock.

\section{CONCLUSION}

Based on the result of research on the effect of return on equity and a weighted average cost of capital on firm value in the textile and garment companies on the Indonesia Stock Exchange. An author can conclude that the relationship between return on equity and the weighted average cost of capital to the firm value is included in the less powerful category. Return on equity and weighted average cost of capital have a significant effect on firm value at textile and garment companies period 2013-2018. 


\section{REFERENCES}

Ali, H. H., \& Miftahurrohman. (2014). Pengaruh Struktur Kepemilikan Saham, Kebijakan Dividen dan Kebijakan Hutang terhadap Nilai Perusahaan (Studi pada Perusahaan Yang Terdaftar di BEI). Jurnal Etikonomi, 13(2), 148-163.

Fahmi, I. (2015). Pengantar Manajemen Keuangan teori dan soal. Bandung: Alfabeta.

Harmono. (2017). Manajemen keuangan berbasis Balanced. Jakarta: PT Bumi angkasa Raya.

IDX. (n.d.). Aktivitas Pencatatan. Retrieved from Https://www.idx.co.id

Kasmir. (2018). Analisis Laporan Keuangan. Jakarta: Raja Grafindo Persada.

Kemenperin. (n.d.). Kemenperin: Industri Tekstil Bidik Ekspor USD 14 Miliar Tahun 2018. Retrieved December 20, 2019, from https://kemenperin.go.id/artikel/19693/Industri-Tekstil-Bidik-Ekspor-USD-14Miliar-Tahun-2018

Lutfiana, A., \& Jhoansyah, R. D. M. D. D. (2019). Analisis Penilaian Harga Wajar Saham dan Keputusan Investasi Secara Fundamental dengan Menggunakan Metode Price Earning Ratio. Jurnal Manajemen Dan Bisnis (Jmb), 20, 1-10.

Puspitasari, D. (2013). Pengaruh Kinerja Keuangan terhadap Nilai Perusahaan (Studi Empiris di Perusahaan Food And Beverages yang Terdaftar pada Bei Tahun 20112013). Jurnal IImu dan Riset Manajemen, 3(6), 1-15.

Rahmantio, I., Saifi, M., \& Nurlaily, F. (2018). Pengaruh Debt to Equity Ratio, Return on Equity, Return on Asset, dan Ukuran Perusahaan terhadap Nilai Perusahaan (Studi pada Perusahaan Pertambangan yang Terdaftar di Bursa Efek Indonesia Tahun 2012-2016). Jurnal Administrasi Bisnis (JAB), 57(1), 151-159.

Sattar, Muhammad Shadab Abdul. (2015). Cost of Capital-The Effect to the Firm Value and Profitability ; Empirical Evidences in Case of Personal Goods (Textile) Sector of KSE 100 Index. Journal of Poverty, Investment and Development, 17, 24-28.

Sudana, I. made. (2015). Manajemen Keuangan Perusahaan (edisi 2). Jakarta: Erlangga.

Sulistiyo, H. (2013). Analisis Struktur Modal Terhadap Wacc Dan Analisis Wacc Terhadap Nilai Perusahaan. 2(01), 260-272.

Suripto. (2015). Manajemen Keuangan: Strategi Penciptaan Nilai. Perusahaan Melalui Pendekatan Economic Value Added. (1st ed.). Bandung: Alfabeta. 